\title{
Dual-height Distribution of Ozone and Nitrogen Oxides during Summer in Urban Tianjin: An Observational Study
}

\author{
Tiantian Zhang1, Weili Lin ${ }^{*}$, Liang Ran², Zhiqiang Ma ${ }^{3}$, Qing Yao ${ }^{4}$, Jingle Liu ${ }^{4}$, Jing Ming 5 \\ ${ }^{1}$ College of Life and Environmental Sciences, Minzu University of China, Beijing 100081, China \\ ${ }^{2}$ Key Laboratory of Middle Atmosphere and Global Environment Observation, Institute of Atmospheric Physics, Chinese \\ Academy of Sciences, Beijing 100029, China \\ ${ }^{3}$ Beijing-Tianjin-Hebei Prediction and Early Warning Center for Environmental Meteorology, Beijing 100089, China \\ ${ }^{4}$ Tianjin Institute of Meteorological Science, Tianjin 300074, China \\ ${ }^{5}$ Beacon Science \& Consulting, Doncaster East, VIC 3109, Australia
}

\begin{abstract}
Measurements of gaseous pollutants, including ozone $\left(\mathrm{O}_{3}\right)$ and nitrogen oxides $\left(\mathrm{NO}_{x}\right)$, were simultaneously conducted at $220 \mathrm{~m}$ (via the installation of an air flow drainage system on a 255-m meteorological tower) and $3 \mathrm{~m}$ above the ground in urban Tianjin during summer 2018. The observed $\mathrm{O}_{3}$ concentrations at the two altitudes exhibited similar diurnal variations but distinctly different values, with higher levels near the surface during the day and the opposite trend at night. Generally higher concentrations of $\mathrm{NO}$ and $\mathrm{NO}_{2}$ were found at $3 \mathrm{~m}$ than $220 \mathrm{~m}$, and the difference in concentration between the two altitudes for the latter pollutant was smaller during daytime and highest at night. $\mathrm{O}_{x}\left(\mathrm{O}_{3}+\mathrm{NO}_{2}\right)$ concentration near the surface during the day, but the difference was negligible at night. Based on the higher $\mathrm{NO}_{x}$ level at $3 \mathrm{~m}$, the photochemical production of $\mathrm{O}_{3}\left(\mathrm{O}_{x}\right)$ at low altitudes intensified during the day, suggesting that the $\mathrm{O}_{3}$ surface concentration was mainly influenced by local photochemical production. Additionally, by measuring the reactive nitrogen $\left(\mathrm{NO}_{y}\right)$ near the surface and calculating $\mathrm{NO}_{z}\left(\mathrm{NO}_{y}-\mathrm{NO}_{x}\right)$, the ozone production efficiency $\left(\mathrm{OPE} ; \mathrm{O}_{x} / \mathrm{NO}_{z}\right)$ in urban Tianjin was assessed for the first time and determined to be $6.0 \pm 0.4$. Compared to the values measured during summer 2010 , lower levels of $\mathrm{NO}_{x}$ but significantly higher ones for $\mathrm{O}_{3}$ were observed during the same season in 2018.
\end{abstract}

Keywords: Nitrogen oxides; Ozone; Vertical observation; Ozone production efficiency.

\section{INTRODUCTION}

Tropospheric ozone $\left(\mathrm{O}_{3}\right)$ exerts a large impact on air quality, environment, and climate change (Tang et al., 2006). Along with rapid economic growth and urbanization, emissions of gaseous pollutants including $\mathrm{O}_{3}$ precursors have largely increased in China. As a result, $\mathrm{O}_{3}$ pollution has become increasingly serious at the urban and regional scales. In the densely populated and economically developed regions of China, such as the Yangtze River Delta, Pearl River Delta, and Beijing-Tianjin-Hebei region, $\mathrm{O}_{3}$ has become a major air pollutant during summer and autumn (Lam et al., 2005; Wang et al., 2006; Ding et al., 2008; Ran et al., 2009; Lu et al., 2010; Tang et al., 2011).

Tropospheric $\mathrm{O}_{3}$ is mainly formed by photochemical reactions of its precursors, nitrogen oxides $\left(\mathrm{NO}_{x}\right)$, and volatile

\footnotetext{
* Corresponding author.

Tel.: +86-10-6893-2633

E-mail address: linwl@muc.edu.cn
}

organic compounds (VOCs) in the presence of sunlight (Haagen-Smit, 1952; Sillman, 2002; Zou et al., 2015). Variations in surface $\mathrm{O}_{3}$ and $\mathrm{NO}_{x}$ concentrations are not only influenced by precursor emissions and photochemical processes but also by transport processes and boundary layer evolution. The advective transport of air pollutants is influenced by the dominant wind direction and topography. Vertical exchange of air pollutants includes both downward transport from high altitude and upward turbulent mixing from the ground. Information on the vertical exchange of air pollutants only based on measurements near the surface can be difficult to obtain. Therefore, obtaining vertical measurements is necessary to understand the characteristics of $\mathrm{O}_{3}$ more thoroughly and its precursors within the boundary layer.

Given the limitations of the current techniques, continuous online monitoring of the vertical distribution of air pollutants within the urban boundary layer is usually based on meteorological towers. Some studies on the vertical profiles of air pollutants such as $\mathrm{O}_{3}, \mathrm{NO}_{x}$, carbon monoxide $(\mathrm{CO})$, sulfur dioxide $\left(\mathrm{SO}_{2}\right)$, particulate matter $(\mathrm{PM})$ and peroxyacetyl nitrate (PAN) in the North China Plain have been based on either the 325-m meteorological tower in Beijing (Liu and 
Hong, 2000; Meng et al., 2002; An et al., 2003; Ding et al., 2005; Sun et al., 2006; An et al., 2007; Ma et al., 2007; Sun et al., 2010) or the 255-m meteorological tower in Tianjin (Han et al., 2009; Huang et al., 2009; Sun et al., 2010; Qiu et al., 2019; Yao et al., 2019). A difference in the concentrations of air pollutants at different heights was noted within the boundary layer. However, due to the limited space and uncontrollable conditions on the tower, the online instruments placed at different heights of the towers are usually not sufficiently maintained to ensure adequate data quality. Additionally, data quality is also restricted by the fluctuation of instrument response with time and the parallelism between instruments. Passive sampling devices are relatively simple, but present low time resolution as a drawback.

Tianjin is located in the North China Plain, where tropospheric $\mathrm{O}_{3}$ is found to be at a considerably high level (Xu and Lin, 2010). $\mathrm{O}_{3}$ pollution has become more severe during the past decades (Li et al., 2019; Lu et al., 2019). Urbanization, economic development, and rapid increase in the number of vehicles (more than 2.88 million in 2018 in Tianjin) caused significant anthropogenic ozone precursor emissions. Therefore, conducting long-term observations of $\mathrm{O}_{3}$ and its precursors at different heights in Tianjin area is crucial. Such studies can provide a scientific basis for taking reasonable and effective measures to mitigate $\mathrm{O}_{3}$ pollution. In this study, an air flow drainage system at a high altitude was built on the $255-\mathrm{m}$ meteorological tower in urban Tianjin. Online instruments on the ground were able to sample air from high altitudes almost without any loss. Concentrations of $\mathrm{O}_{3}$ and $\mathrm{NO}_{x}$ were simultaneously measured at a height of $220 \mathrm{~m}$ and $3 \mathrm{~m}$ above ground level to study the characteristics of these gases at different heights.

\section{METHODS}

The observational site is located in the yard of Tianjin
Atmospheric Boundary Observatory (TABO) of the China Meteorological Administration $\left(39^{\circ} 06^{\prime} \mathrm{N}, 117^{\circ} 10^{\prime} \mathrm{E}, 2.2 \mathrm{~m}\right.$ a.s.l.), which is in the southern part of urban Tianjin. It is surrounded by residential and commercial areas and is approximately $100 \mathrm{~m}$ away from a freeway to its north.

An air drainage system (Fig. 1) with the inlet placed at a height of $220 \mathrm{~m}$ above ground level was situated on the 255m-high meteorological tower in TABO. Air from a height of $220 \mathrm{~m}$ could be drained into a Teflon tube and eventually entered the online instruments in an air-conditioned room on the ground. The air drainage system mainly contains a large-caliber Teflon tube (Shanghai Huzhuang Rubber Plastic Products Co., Ltd., China) with an I.D. of $3.2 \mathrm{~cm}$ and an O.D. of $3.6 \mathrm{~cm}$ and a rotary vane pump (GAST1423101Q-G626X; Gast Manufacturing, Inc., USA) with a free air flow of $20 \mathrm{~m}^{3} \mathrm{~h}^{-1}$ under an air pressure of approximately 1 bar. To prevent the entry of rain and insects into the pipeline, a protection cover was equipped in front of the inlet. The Teflon pipe was wrapped using aluminum foils to shield it from sunlight. The retention time of the air in the drainage system was less than $35 \mathrm{~s}$. An air flow distributor with eight branch pipes was installed between the pipe and the pump. Through the branched pipes, air could be sampled and analyzed using different instruments. A pressure meter probe was also placed in the distributor to monitor the air flow pressure. Difference in pressures between the inlet (at $220 \mathrm{~m}$ high) and the distributor was less than $20 \mathrm{hPa}$. Condensed water (if any) in the buffer bottle could be automatically drained off by a little pump (Shenzhen Sypda Technology Co., Ltd., China) to prevent water from accumulating in the pipe and entering the analyzers. The rotary vane pump was protected by a high-volume particulate filter. Using a time controller and 3-way solenoid valve, air at $220 \mathrm{~m}$, surface air, zero gas, and span gases could be subsequently switched in the analyzers. Accordingly, gas pollutants at different heights could be conveniently measured near the surface.
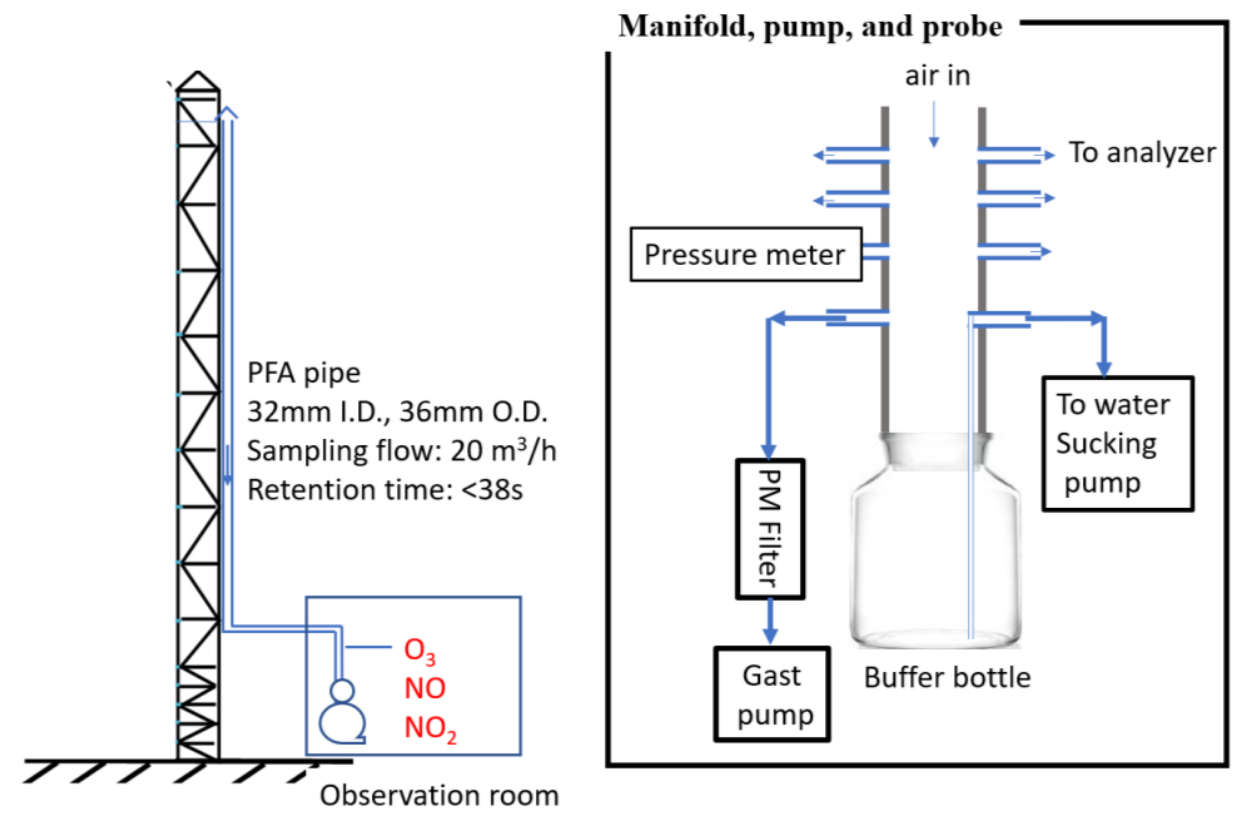

Fig. 1. An air flow drainage system based on a 255-m-high meteorological tower in urban Tianjin. 
Instrument calibration and maintenance could also be easily performed on the ground. This system helps in overcoming the space limit of the tower.

Field observations of $\mathrm{O}_{3}, \mathrm{NO}_{2}$, and $\mathrm{NO}$ at two heights were obtained using this air flow drainage system from June 1 to August 31, 2018. The air-sample collection was switched every $15 \mathrm{~min}$ between $220 \mathrm{~m}$ and $3 \mathrm{~m}$. Reactive nitrogen $\left(\mathrm{NO}_{y}\right)$ was only measured near the surface because $\mathrm{NO}_{y}$ compounds other than NO must first be transformed into NO before they can be measured using chemiluminescence. They were converted to NO by using a molybdenum converter heated to approximately $375^{\circ} \mathrm{C}$. $\mathrm{NO}_{y}$ includes all reactive oxides of nitrogen (i.e., $\mathrm{NO}, \mathrm{NO}_{2}, \mathrm{NO}_{3}, \mathrm{~N}_{2} \mathrm{O}_{5}, \mathrm{HNO}_{2}$, $\mathrm{HNO}_{3}$, PAN, organic nitrates, and aerosol nitrates). To minimize the loss of $\mathrm{NO}_{y}$ prior to measurement, an external molybdenum converter was used to limit sample transport time and surface contact area. Thus, the external converter was only deployed near ground level. Data were recorded every $1 \mathrm{~min}$. Information on the gas analyzers is presented in Table 1.

Three aspects of quality control were considered during the measurement:

(1) To determine the effect of gas loss in the pipeline, $\mathrm{O}_{3}$ loss test was performed. From August 16 to September $30,2017, \mathrm{O}_{3}$ concentrations at the inlet and outlet of the pipeline were tested in parallel by using two $\mathrm{O}_{3}$ analyzers. Comparison between measurement results (Fig. 2) from two instruments revealed the negligible loss of $\mathrm{O}_{3}$ in the pipeline.

(2) Standard gases were used to calibrate the instruments. The $\mathrm{O}_{3}$ analyzer was calibrated using an $\mathrm{O}_{3}$ calibrator (Model 49i-PS; Thermo Fisher Scientific, USA). An $\mathrm{NO} / \mathrm{N}_{2}$ mixed reference gas (Beijing Huayuan Gas Chemical Co., Ltd., China), gas dynamic calibrator (Model 146i; Thermo Fisher Scientific, USA), and zerogas generator (Model 111i; Thermo Fisher Scientific, USA) were used for multipoint calibration of the $\mathrm{NO}_{y}$ instrument and for the $\mathrm{NO}_{2}$ analyzer through the gasphase titration method.

(3) Data correction and rejection were performed. Original data was corrected using multipoint calibration results. Each time the sampled air was switched from one height to another, a balancing time of 2 min was required, and the corresponding data was eliminated. The corrected data were further processed into hourly averages for subsequent analysis.

\section{RESULTS AND DISCUSSION}

\section{Variations in $\mathrm{O}_{3}, \mathrm{NO}$, and $\mathrm{NO}_{2}$ at Different Heights}

Fig. 3 displays the time series of $\mathrm{O}_{3}$ concentrations at different heights during the observational period. The missing data are due to instrument calibration, instrument malfunction, power failure, station renewal program, etc. Apparently, the variations in $\mathrm{O}_{3}$ concentrations at two heights basically shared a similar diurnal pattern, with high values in the daytime

Table 1. Information on instruments.

\begin{tabular}{lllll}
\hline $\mathrm{Gas}$ & Instrument & Manufacturer & Minimum detection limit & Principle of the instrument \\
\hline $\mathrm{O}_{3}$ & Model $49 i$ & $\begin{array}{l}\text { Thermo Fisher } \\
\text { Scientific, USA }\end{array}$ & $0.5 \mathrm{ppb}$ & UV photometry \\
$\mathrm{NO}_{2}$ & LGR's NO ${ }_{2}$ Analyzer & $\begin{array}{l}\text { Los Gatos Research, } \\
\text { Inc., USA }\end{array}$ & $0.01 \mathrm{ppb}$ \\
$\mathrm{NO} / \mathrm{NO}_{y}$ & Model $42 i-\mathrm{Y}$ & $\begin{array}{l}\text { Thermo Fisher } \\
\text { Scientific, USA }\end{array}$ & $0.05 \mathrm{ppb}$ & $\begin{array}{l}\text { Cavity-enhanced laser } \\
\text { absorption spectroscopy } \\
\text { Chemiluminescence with } \\
\text { Mo-converter }\end{array}$ \\
\hline
\end{tabular}

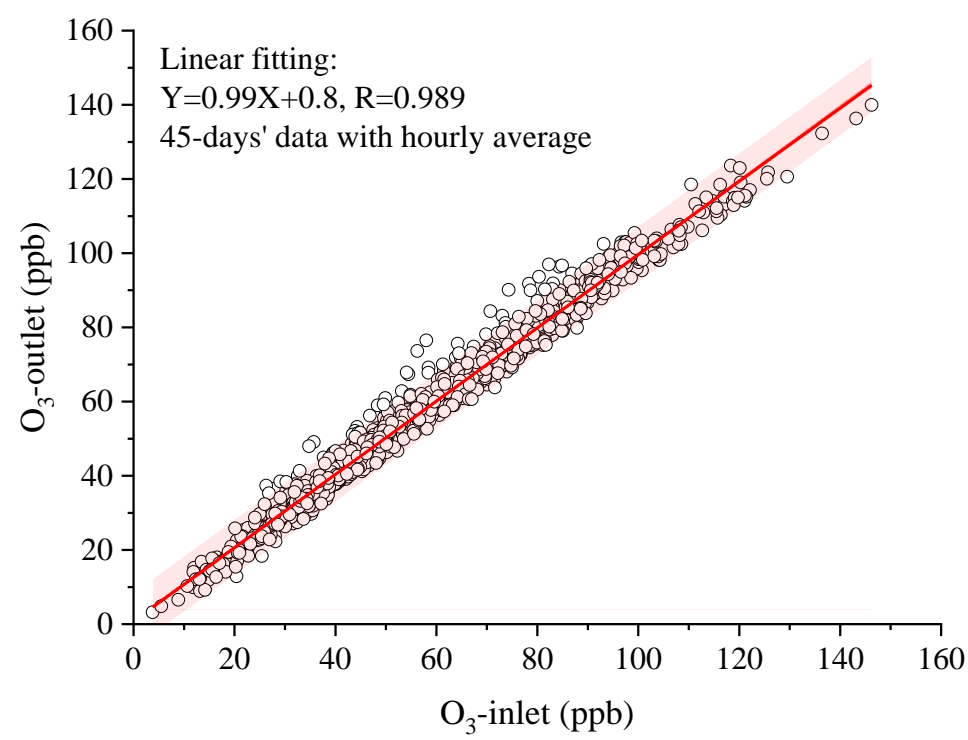

Fig. 2. Relationship between $\mathrm{O}_{3}$ concentrations at the inlet and outlet of the airflow drainage system. 


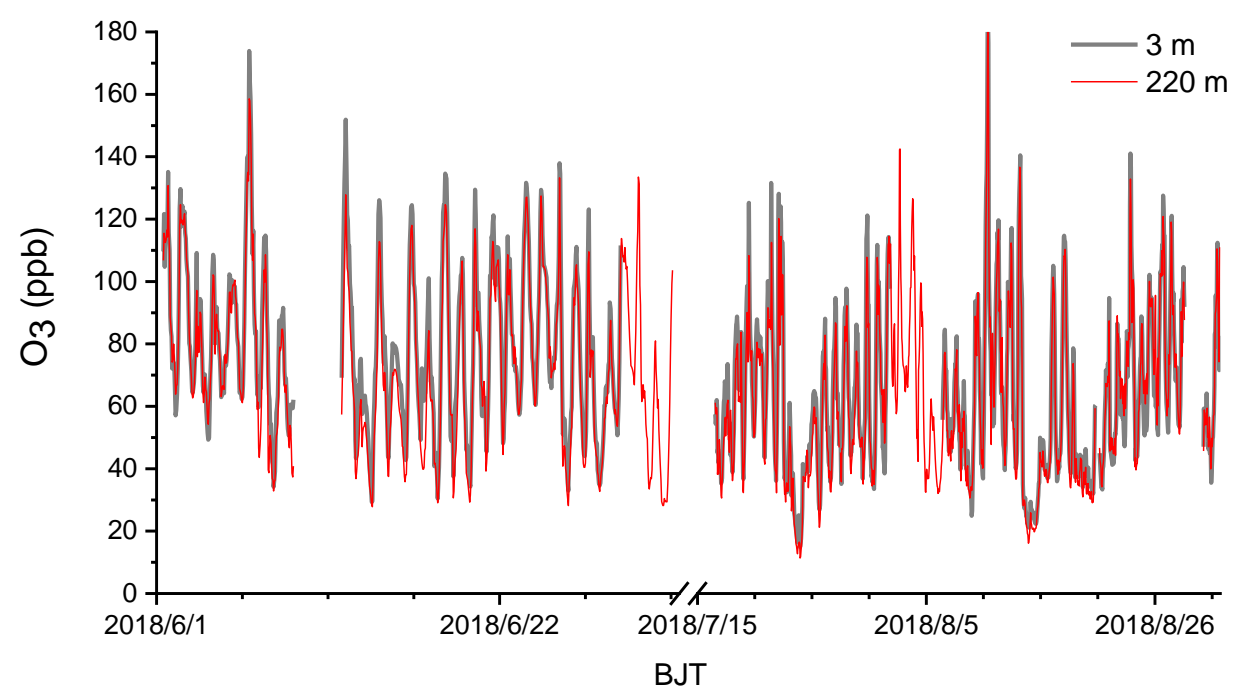

Fig. 3. Time series of $\mathrm{O}_{3}$ concentrations at different heights in urban Tianjin.

and low values at night. Influenced by weather processes, $\mathrm{O}_{3}$ concentrations experienced several accumulation-decline cycles, each usually lasting for 7-10 days. Overall, there were 131 hours of $\mathrm{O}_{3}$ concentrations exceeding $100 \mathrm{ppb}$ from the 1673-h valid data near the surface and 121 hours of $\mathrm{O}_{3}$ concentrations exceeding $100 \mathrm{ppb}$ from the 1864-h valid data at $220 \mathrm{~m}$.

Table 2 presents the descriptive statistics of $\mathrm{O}_{3}, \mathrm{NO}_{2}, \mathrm{NO}$, and $\mathrm{O}_{x}$ concentrations at two sample heights. A one-to-one correspondence between the data for the two heights was adopted to improve the reliability of the comparison.

The statistical analysis of $\mathrm{O}_{3}$ concentrations at different heights is also presented in Fig. S1. Surface $\mathrm{O}_{3}$ level was greater than that at high altitude toward the higher end of the concentration distribution (e.g., the $95 \%$ highest value was $109.2 \mathrm{ppb}$ near the surface and $104.1 \mathrm{ppb}$ at $220 \mathrm{~m}$ ). By contrast, surface $\mathrm{O}_{3}$ level was lower than that at high altitude toward the lower end of the concentration distribution (e.g., the $5 \%$ lowest value was $10.3 \mathrm{ppb}$ near the surface and $15.8 \mathrm{ppb}$ at $220 \mathrm{~m})$. The average $(53.2 \pm 30.6 \mathrm{ppb})$ and median ( $48.8 \mathrm{ppb}$ ) values of surface $\mathrm{O}_{3}$ concentrations were slightly lower than the average $(53.8 \pm 27.7 \mathrm{ppb})$ and median $(49.9 \mathrm{ppb})$ values at $220 \mathrm{~m}$. The difference between the daily mean $\mathrm{O}_{3}$ concentrations at $3 \mathrm{~m}$ and $220 \mathrm{~m}$ ranged from $-18.0 \mathrm{ppb}$ to $12.0 \mathrm{ppb}$. Variations in daytime $\mathrm{O}_{3}$ concentration were mainly influenced by processes such as transport (advection or vertical mixing), photochemical reaction, and deposition. High $\mathrm{O}_{3}$ concentrations were mainly noted during the afternoon, and low $\mathrm{O}_{3}$ concentrations were mainly noted during the night. Surface concentration was lower than that at $220 \mathrm{~m}$ during the night, indicating that near-surface $\mathrm{O}_{3}$ may be consumed through NO titration more easily than that at $220 \mathrm{~m}$ (Han et al., 2009). This result differs from that reported by Sun et al. (2010), who measured $\mathrm{O}_{3}$ concentration at three heights $(40 \mathrm{~m}, 120 \mathrm{~m}$, and $220 \mathrm{~m})$ in the same tower from August 18 to September 22, 2006; they found that $\mathrm{O}_{3}$ concentration always increased with height. The difference in the vertical distributions between 2006 and 2018 may have been due to the substantial changes in population, urbanization, and pollutant emission in Tianjin.

Figs. 4 and 5 display the time series of hourly mean $\mathrm{NO}_{2}$ and NO concentrations at different heights during the observational period. Obvious diurnal variations were observed, with a higher level during the night than in the daytime. NO peaked almost at the same time at different heights, whereas $\mathrm{NO}_{2}$ peaked at different times, with a later appearance of the maximum concentration at $220 \mathrm{~m}$. According to the statistical results shown in Table 2 and Fig. S2, $\mathrm{NO}_{2}$ concentration near the surface was significantly higher than that at $220 \mathrm{~m}$ for all conditions. NO concentration near the surface was obviously higher than that at $220 \mathrm{~m}$ toward the higher end of the concentration distribution, but remained comparable to that at $220 \mathrm{~m}$ toward the lower end of the concentration distribution.

The average value of the surface $\mathrm{NO}_{2}$ hourly mean ( \pm 1 standard deviation) was $15.36 \pm 8.15 \mathrm{ppb}$, with a median value of $14.17 \mathrm{ppb}$. The mean value of $\mathrm{NO}_{2}$ at $220 \mathrm{~m}$ was $10.98 \pm 6.34 \mathrm{ppb}$, with a median value of $9.40 \mathrm{ppb}$. The average value of the surface NO was $1.65 \pm 3.22 \mathrm{ppb}$, with a median value of $0.92 \mathrm{ppb}$. The average value of the highaltitude NO was $1.13 \pm 1.40 \mathrm{ppb}$, with a median value of $0.86 \mathrm{ppb}$. A two-sided reduced major axis regression was conducted for $\mathrm{NO}_{2}$ and $\mathrm{NO}$ at different heights. The slopes of $\mathrm{NO}_{2} / \mathrm{NO}$ were $2.35 \pm 0.07\left(\mathrm{R}^{2}=0.156, \mathrm{P}<0.05\right)$ near ground level and $4.45 \pm 0.12\left(\mathrm{R}^{2}=0.244, \mathrm{P}<0.05\right)$ at $220 \mathrm{~m}$. Higher $\mathrm{NO}_{2} / \mathrm{NO}$ values indicated more photochemically aged air mass at $220 \mathrm{~m}$. The average value of surface NO was significantly higher than the median value and considerable amounts of newly emitted NO were observed near ground level, suggesting the effects of local pollution.

\section{Diurnal Variations}

Fig. 6 depicts the average diurnal variations of $\mathrm{O}_{3}, \mathrm{NO}_{2}$, $\mathrm{O}_{x}\left(\mathrm{O}_{3}+\mathrm{NO}_{2}\right)$, and $\mathrm{NO}$ at $3 \mathrm{~m}$ and $220 \mathrm{~m}$ during the observational period. In general, similar diurnal variations were found at different heights for each of the gases.

$\mathrm{O}_{3}$ increased rapidly after sunrise and maintained a high value between 12:00 and 16:00. Thereafter, the concentration 
Table 2. Descriptive statistics of $\mathrm{O}_{x}, \mathrm{O}_{3}, \mathrm{NO}_{2}$, and $\mathrm{NO}$ concentrations at two heights.

\begin{tabular}{|c|c|c|c|c|c|c|c|c|}
\hline & \multicolumn{2}{|c|}{$\mathrm{O}_{x}$} & \multicolumn{2}{|c|}{$\mathrm{O}_{3}$} & \multicolumn{2}{|c|}{$\mathrm{NO}_{2}$} & \multicolumn{2}{|c|}{$\mathrm{NO}$} \\
\hline & $3 \mathrm{~m}$ & $220 \mathrm{~m}$ & $3 \mathrm{~m}$ & $220 \mathrm{~m}$ & $3 \mathrm{~m}$ & $220 \mathrm{~m}$ & $3 \mathrm{~m}$ & $220 \mathrm{~m}$ \\
\hline Mean (ppb) & 69.4 & 65.8 & 53.2 & 53.8 & 15.36 & 10.98 & 1.65 & 1.13 \\
\hline $\mathrm{SD}(\mathrm{ppb})$ & 27.0 & 26.2 & 30.6 & 27.7 & 8.15 & 6.34 & 3.22 & 1.40 \\
\hline $\operatorname{Min}(\mathrm{ppb})$ & 14.9 & 11.4 & 3.7 & 3.7 & 2.58 & 0.54 & 0.11 & 0.11 \\
\hline P5 (ppb) & 33.6 & 30.6 & 10.3 & 15.8 & 4.86 & 3.81 & 0.39 & 0.39 \\
\hline P25 (ppb) & 48.0 & 45.2 & 28.9 & 31.3 & 9.31 & 6.38 & 0.64 & 0.60 \\
\hline Median (ppb) & 65.1 & 62.8 & 48.8 & 49.9 & 14.17 & 9.40 & 0.92 & 0.86 \\
\hline P75 (ppb) & 87.4 & 83.0 & 74.1 & 72.9 & 20.11 & 14.13 & 1.46 & 1.13 \\
\hline P95 (ppb) & 119.2 & 112.5 & 109.2 & 104.1 & 30.28 & 23.08 & 4.55 & 2.58 \\
\hline Max (ppb) & 185.1 & 181.3 & 176.9 & 174.7 & 52.68 & 42.08 & 45.18 & 23.61 \\
\hline Count (hour) & 1550 & 1550 & 1673 & 1673 & 1550 & 1550 & 987 & 987 \\
\hline
\end{tabular}

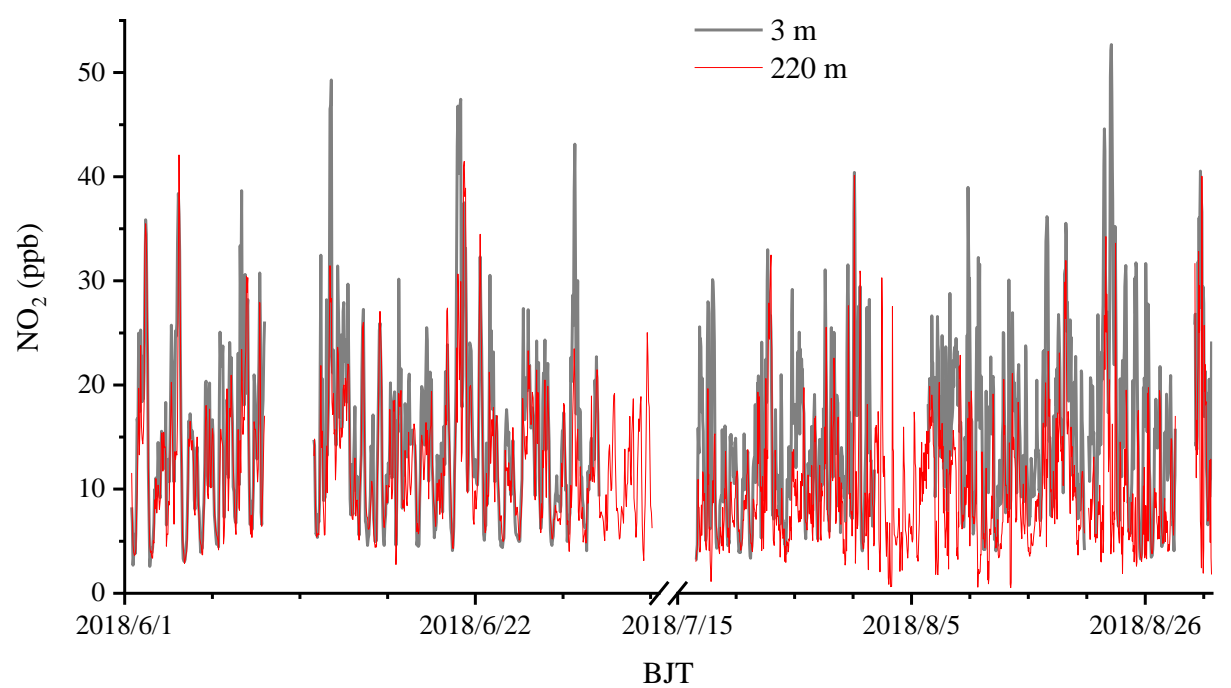

Fig. 4. Time series of $\mathrm{NO}_{2}$ concentrations at different heights in urban Tianjin.

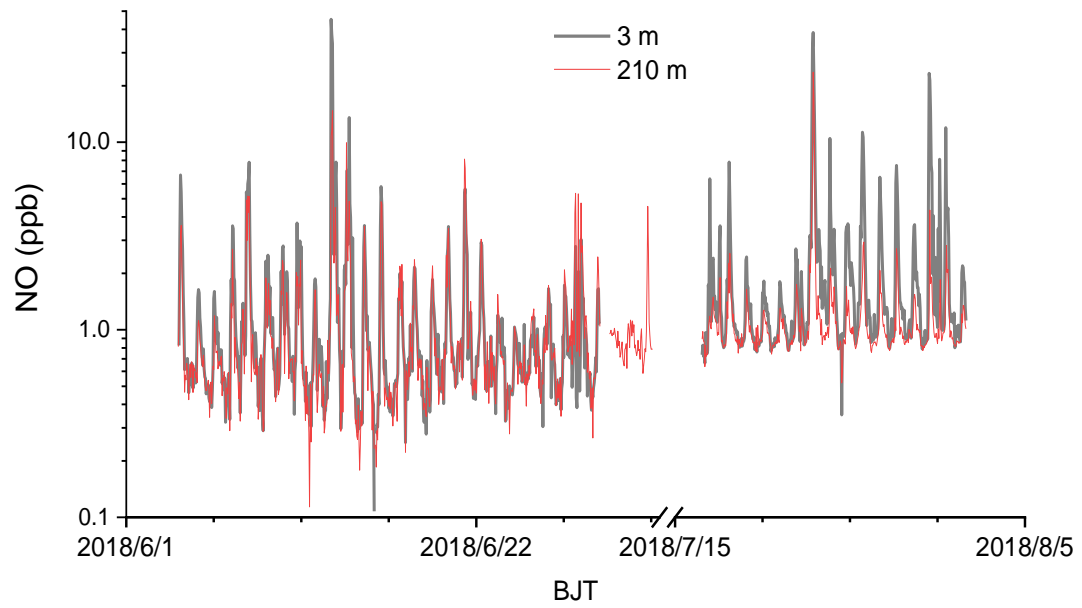

Fig. 5. Time series of NO concentrations at different heights in urban Tianjin.

began to decline until the early hours of midnight. During the day (08:00-17:00), $\mathrm{O}_{3}$ concentration was higher near ground level than at $220 \mathrm{~m}$ (the average difference was $4.0 \mathrm{ppb}$, and the maximum difference was approximately $6.0 \mathrm{ppb}$; Fig. 6(a)). The daytime variations of vertical $\mathrm{O}_{3}$ distribution differed from those reported in previous studies.
Sun et al. (2010) reported that $\mathrm{O}_{3}$ concentration increased with height, with a considerably higher $\mathrm{O}_{3}$ gradient during the night than during the daytime. These measurements were taken from August 18 to September 22, 2006. Han et al. (2009) and Huang et al. (2009) reported similar variations with measurements taken during September-November 
2006 and August 4-24, 2007, respectively. Qiu et al. (2019) reported very similar $\mathrm{O}_{3}$ values at two heights during 09:0016:00 and higher values at higher altitudes after 16:00 during September 2018. These results were observed at the same site but during different years and seasons, which may have resulted in complex changes in the vertical variation in $\mathrm{O}_{3}$ concentration during different periods in urban Tianjin. Further exploration involving measurements of VOCs is warranted. At night (21:00-06:00), surface $\mathrm{O}_{3}$ concentration was lower than that in the upper level (an average difference was $7.0 \mathrm{ppb}$ and the highest was close to $9.0 \mathrm{ppb}$ ), although the difference seems less than that in 2006 (30-50 ppb; Han et al., 2009; Sun et al., 2010). During early morning (around 07:00) and in the evening (17:00-20:00), $\mathrm{O}_{3}$ concentrations at different heights were nearly the same. As seen in Fig. 6, $\mathrm{O}_{3}$ concentrations at different heights began to rise in the early morning. Sunrise during summer was at about 05:00, when the boundary layer begins to elevate. Air in the upper layer (or residual layer) started to mix downward with the air in the lower layer, resulting in a rise in the $\mathrm{O}_{3}$ concentration near the surface and more uniform distribution through different layers. Along with the further development of the boundary layer under stronger and stronger solar radiation, surface $\mathrm{O}_{3}$ gradually exceeded aloft $\mathrm{O}_{3}$ through the photochemical generation. Evidently, the photochemical production of $\mathrm{O}_{3}$ near the surface was higher than that at higher altitudes, especially during 08:00-17:00 when photochemical reactions were active. Near ground level, $\mathrm{O}_{3}$ may be more easily depleted through deposition than at $220 \mathrm{~m}$. If the $\mathrm{O}_{3}$ concentration is higher in the upper level, then the surface $\mathrm{O}_{3}$ cannot be increased through downward mixing. More $\mathrm{O}_{3}$ precursors near ground level might be essential for determining the difference in vertical $\mathrm{O}_{3}$ concentration during the daytime.

The diurnal variation in $\mathrm{NO}_{2}$ concentration (Fig. 6(b)) shows morning and evening peaks around 07:00 and 19:00, respectively. This was particularly evident at $220 \mathrm{~m}$. Surface $\mathrm{NO}_{2}$ concentration remained relatively high after 19:00. $\mathrm{NO}_{2}$ concentration gradually decreased before noon and reached the lowest during 12:00-16:00, contrary to the variation in the $\mathrm{O}_{3}$ concentration. In general, $\mathrm{NO}_{2}$ concentration near the surface was higher than that at $220 \mathrm{~m}$, but the two were comparable during the day. The difference between $\mathrm{NO}_{2}$ concentrations at different heights increased during the night, with the maximum exceeding $9 \mathrm{ppb}$, possibly due to the accumulation of emitted $\mathrm{NO}_{2}$ near the ground and weak vertical mixing.

From Fig. 6(d), the diurnal variation of NO is noted to be characterized by a unimodal type, with a peak during 06:0010:00 and a higher level at night than in the day. The time when NO concentration peaked during early morning was slightly different for different heights. The concentration of NO near the surface was higher than that at $220 \mathrm{~m}$, with the largest difference during the day and the smallest at night. Therefore, $\mathrm{O}_{3}$ was significantly affected by chemical titration of NO at night, especially near the surface, leading to a much higher level at $220 \mathrm{~m}$ than near the surface. In 2006, the average diurnal change of $\mathrm{NO}_{x}$ is with an evident peak around 14:00 (Sun et al., 2010), but this afternoon peak is not found in 2018.

In cities, $\mathrm{O}_{x}\left(\mathrm{O}_{x}=\mathrm{O}_{3}+\mathrm{NO}_{2}\right)$ is usually used to represent the total oxidant in the atmosphere. Being more conservative than $\mathrm{O}_{3}, \mathrm{O}_{x}$ can better characterize the photochemical process, as rapid $\mathrm{NO}_{x}-\mathrm{O}_{3}$ cycle (Liu, 1977; Nunnermacker et al., 1998) need not be considered. As seen in Fig. 6(c), $\mathrm{O}_{x}$ showed similar variation as $\mathrm{O}_{3}$, except the small difference in $\mathrm{O}_{x}$ at
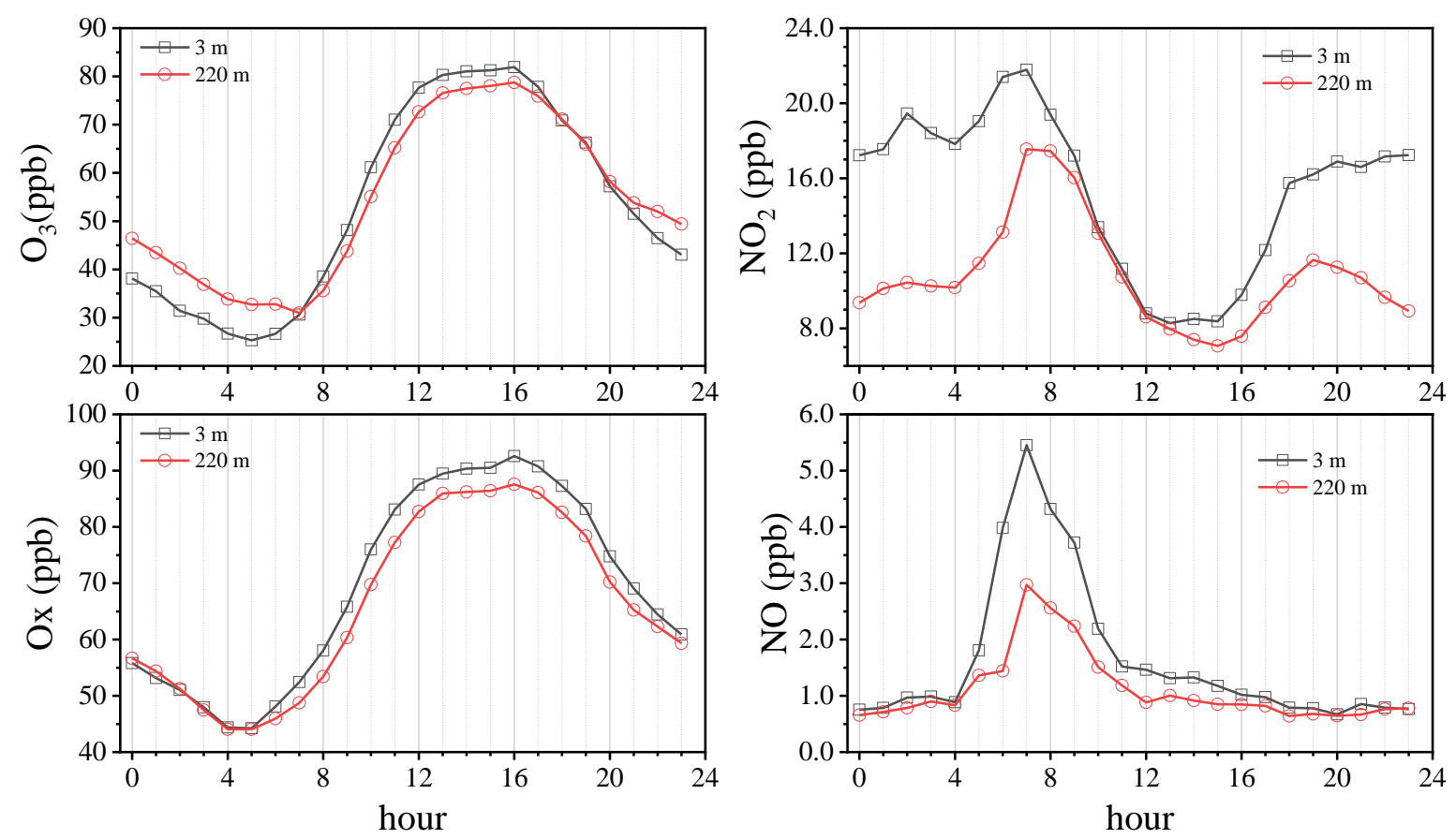

Fig. 6. Average diurnal variations of $\mathrm{O}_{3}, \mathrm{NO}_{2}, \mathrm{O}_{x}\left(\mathrm{O}_{3}+\mathrm{NO}_{2}\right)$, and $\mathrm{NO}$ concentrations at different heights during the observational period. 
different heights during the night (especially from midnight to early morning). The concentration increased rapidly after sunrise and reached the maximum at approximately 16:00. The peak of the mean concentration was $87.6 \mathrm{ppb}$ at $220 \mathrm{~m}$ and $92.6 \mathrm{ppb}$ near the surface. During the day, the $\mathrm{O}_{x}$ concentration was considerably higher near ground level than at $220 \mathrm{~m}$, with the maximum difference exceeding $6 \mathrm{ppb}$. As shown in Table 2, for the 1550 pairs of hourly mean $\mathrm{O}_{x}$ concentrations, the average $(69.4 \pm 27.0 \mathrm{ppb})$, median (65.1 ppb), minimum (14.9 ppb), and maximum (185.1 ppb) values of surface $\mathrm{O}_{x}$ concentration were 3-4 ppb higher than the average $(65.9 \pm 27.0 \mathrm{ppb})$, median $(62.8 \mathrm{ppb})$, minimum (11.4 ppb), and maximum (181.3 ppb) values at $220 \mathrm{~m}$. Therefore, total oxidant production was considerably stronger near ground level than at $220 \mathrm{~m}$ during summer in urban Tianjin.

According to the aforementioned analysis, the concentration of $\mathrm{O}_{3}$ precursor, $\mathrm{NO}_{x}$, was higher near the surface than at $220 \mathrm{~m}$ in urban Tianjin. During the day, photochemical generation of $\mathrm{O}_{3}\left(\mathrm{O}_{x}\right)$ was greater than that at $220 \mathrm{~m}$. Thereafter, the rapid increase in the $\mathrm{O}_{3}$ concentration was mainly affected by local photochemical formation and not by downward mixing of the residual layer. From 07:00 to 14:00, $\mathrm{O}_{3}$ concentration on an average increased to approximately $50 \mathrm{ppb}$ near the surface and $46 \mathrm{ppb}$ at $220 \mathrm{~m}$.

\section{Comparison of $\mathrm{O}_{3}$ and $\mathrm{NO}_{2}$ Concentrations between 2010 and 2018}

Fig. 7 depicts the time series of $\mathrm{O}_{3}$ and $\mathrm{NO}_{2}$ hourly mean concentrations during summer at the same site in Tianjin in different years (2010 and 2018); the observation data in 2010 are available in Ran et al. (2012). The measurements in 2010 and 2018 were performed at the same location. $\mathrm{O}_{3}$ concentrations at both times were measured using UV photometric $\mathrm{O}_{3}$ analyzers. These analyzers were calibrated using a primary standard UV photometric $\mathrm{O}_{3}$ calibrator, which is traceable to the standard reference photometer maintained at the World Calibration Centre of the World
Meteorological Organization in EMPA, Switzerland. NO analyzers were operated according to the principles of chemiluminescence. In contrast to the direct measurement process implemented in 2018, that adopted in 2010 involved first converting $\mathrm{NO}_{2}$ into $\mathrm{NO}$ by using a molybdenum converter heated to approximately $325^{\circ} \mathrm{C}$ and then performing measurements using chemiluminescence. The $\mathrm{NO} / \mathrm{N}_{2}$ standard mixtures for in situ calibrations were compared with the same NO standard produced by Scottgas (https://industry.airliquide.us/scott-gas-mixtures), which can be traced to the National Institute of Standards and Technology (Lin et al., 2011). NO was converted into $\mathrm{NO}_{2}$ through gas-phase titration for $\mathrm{NO}_{2}$ calibration. Therefore, comparison of data from 2010 and 2018 was sound. Because insufficient data prevented meaningful statistical analysis (only 381 hourly overlapping NO observations), $\mathrm{NO}$ and $\mathrm{NO}_{x}$ were not compared for these periods.

Compared with the data in $2010, \mathrm{NO}_{2}$ concentrations in 2018 were significantly lower, whereas the range of $\mathrm{O}_{3}$ concentrations was similar but with higher $\mathrm{O}_{3}$ peaks in 2018 . From the statistical data (Table 2 and Fig. S3), hourly mean $\mathrm{NO}_{2}$ concentration was found to be $15.70 \pm 0.27 \mathrm{ppb}$ and the median value was $14.58 \mathrm{ppb}$ in 2018 , whereas the hourly mean was $25.51 \pm 0.39 \mathrm{ppb}$ and the median was $24.54 \mathrm{ppb}$ in 2010. The difference in $\mathrm{NO}_{2}$ mean was close to $10 \mathrm{ppb}$. The average $\mathrm{O}_{3}$ hourly mean was $39.0 \pm 0.9 \mathrm{ppb}$ in 2010 and $47.0 \pm 1.0 \mathrm{ppb}$ in 2018 , and the $\mathrm{O}_{3}$ median values were 31.2 ppb in 2010 and 41.0 ppb in 2018, respectively. Even for the lower end of the concentration distribution, $\mathrm{O}_{3}$ concentration was slightly higher in 2018 than in 2010. For example, $\mathrm{O}_{3}$ concentration was $24.2 \mathrm{ppb}$ in 2018 and $14.6 \mathrm{ppb}$ in 2010 for $25 \%$ of the lowest value.

The comparability of pollutant concentrations in different years depends not only on changes in source emissions but also on weather conditions. The weather influences atmospheric diffusion, transmission, and photochemical reactions, and conditions vary from year to year. During the comparison periods, the average temperatures were $25.7^{\circ} \mathrm{C}$

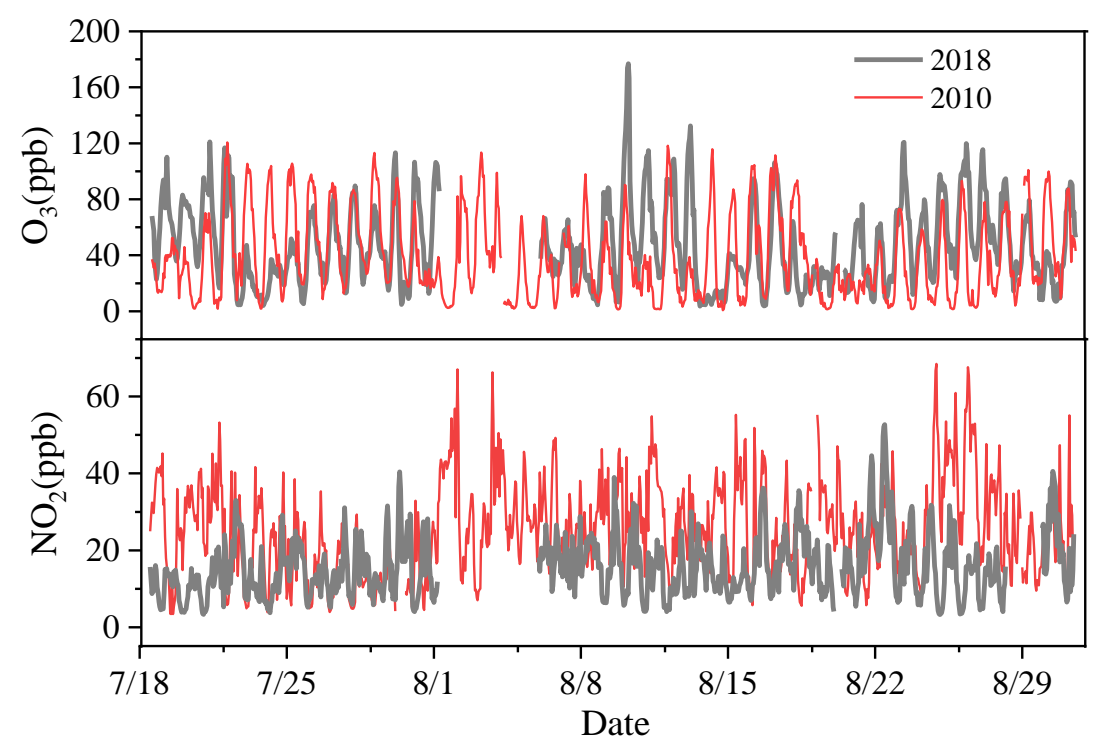

Fig. 7. Time series of $\mathrm{O}_{3}$ and $\mathrm{NO}_{2}$ concentrations in different years in urban Tianjin. 
in 2010 and $29.5^{\circ} \mathrm{C}$ in 2018 , the average relative humidity (RH) recordings were $64 \%$ in 2010 and $67 \%$ in 2018, and the average wind speeds were $0.9 \mathrm{~m} \mathrm{~s}^{-1}$ in 2010 and $1.9 \mathrm{~m} \mathrm{~s}^{-1}$ in 2018. The prevailing wind was from east in 2018 and from the west and north in 2010. To minimize the effects of meteorological variations, $\mathrm{O}_{3}$ and $\mathrm{NO}_{2}$ concentrations from 2010 and 2018 were reclassified and averaged according to temperature, relative humidity, wind speed, and wind direction, as suggested by Lin et al. (2012). Thus, the differences were evaluated for various meteorological categories, and the results are shown in Figs. 8 and 9. It is worth noting that less proportions of data could be found in the lowest or the highest values of bins. For example, the frequency of wind speed higher than $3 \mathrm{~m} \mathrm{~s}^{-1}$ only took up a factor of less than $6 \%$ in 2018 . Temperatures between $22^{\circ} \mathrm{C}$ and $35^{\circ} \mathrm{C}$ comprised $93.5 \%$ and $94.4 \%$ of the recordings in 2018 and 2010, respectively.

As shown in Fig. 8, the concentration of $\mathrm{O}_{3}$ increased with temperature; as $\mathrm{RH}$ and wind speed increased, $\mathrm{O}_{3}$ concentration increased and then decreased. The differences between the $\mathrm{O}_{3}$ concentrations in 2010 and 2018 were noticeable for the $\mathrm{RH}$ and wind direction categories, with considerably higher concentrations in 2018 than in 2010. However, the differences were more complex for the temperature and wind speed categories, possibly as a result of the interaction effect of temperature and wind speed. Generally, higher temperature resulted in higher wind speeds, and high wind speed could reduce the ground-level $\mathrm{O}_{3}$ concentration.

As shown in Fig. 9, the concentration of $\mathrm{NO}_{2}$ increased with $\mathrm{RH}$ and decreased with the increasing temperature and wind speed. Because limited data were available from 2010 for temperatures higher than $34^{\circ} \mathrm{C}$, the concentrations of $\mathrm{NO}_{2}$ were considerably higher in 2010 than in 2018 for various meteorological categories. Therefore, emission reduction should effectively reduce $\mathrm{NO}_{2}$ concentrations. This can be confirmed by decreasing tropospheric $\mathrm{NO}_{2}$ column density in Tianjin since 2010 (You et al., 2016), according to satellite observations, and the decreasing trend observed in routine $\mathrm{NO}_{2}$ measurements in the 2018 Tianjin Ecology and Environment Statement.

In summary, $\mathrm{O}_{3}$ concentration during summer in Tianjin increased from 2010 to 2018, whereas $\mathrm{NO}_{2}$ concentration decreased.

\section{Ozone Production Efficiency}

Based on ground measurements, the relationship between $\mathrm{O}_{x}\left(\mathrm{O}_{x}=\mathrm{O}_{3}+\mathrm{NO}_{2}\right)$ and $\mathrm{NO}_{z}\left(\mathrm{NO}_{z}=\mathrm{NO}_{y}-\mathrm{NO}_{x}\right)$ was calculated and ozone production efficiency (OPE) was obtained from the slope of the correlation. Fig. 10 depicts the correlation between $\mathrm{O}_{x}$ and $\mathrm{NO}_{z}$ from 11:00 to 16:00 during the observational period. Linear regression was performed using a reduced major axis regression method. A significant correlation was noted at the confidence level of 0.05 , and the correlation coefficient (R) was 0.434 . From the slope of the correlation, OPE in summer in urban Tianjin was determined to be $6.0 \pm 0.4$. This value falls within the OPE values measured in other urban areas (Ge et al., 2010).

A lack of measurements of VOCs makes ozone sensitivity difficult to discuss. Previous studies have suggested that $\mathrm{O}_{3}$
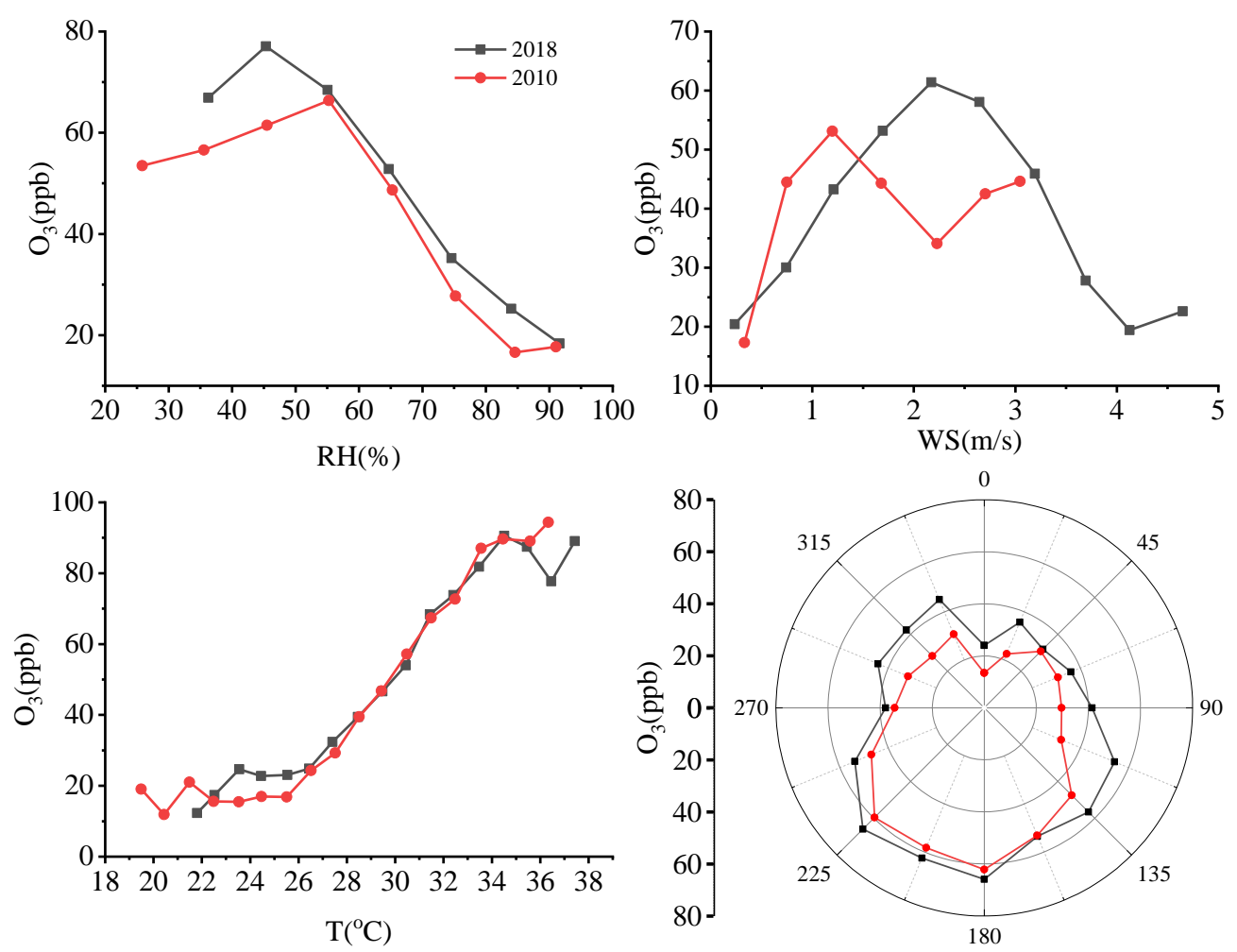

Fig. 8. Mixing ratios of $\mathrm{O}_{3}$ in 2010 and in 2018 as functions of (a) relative humidity, (b) wind speed, (c) ambient temperature, and (d) wind direction. 

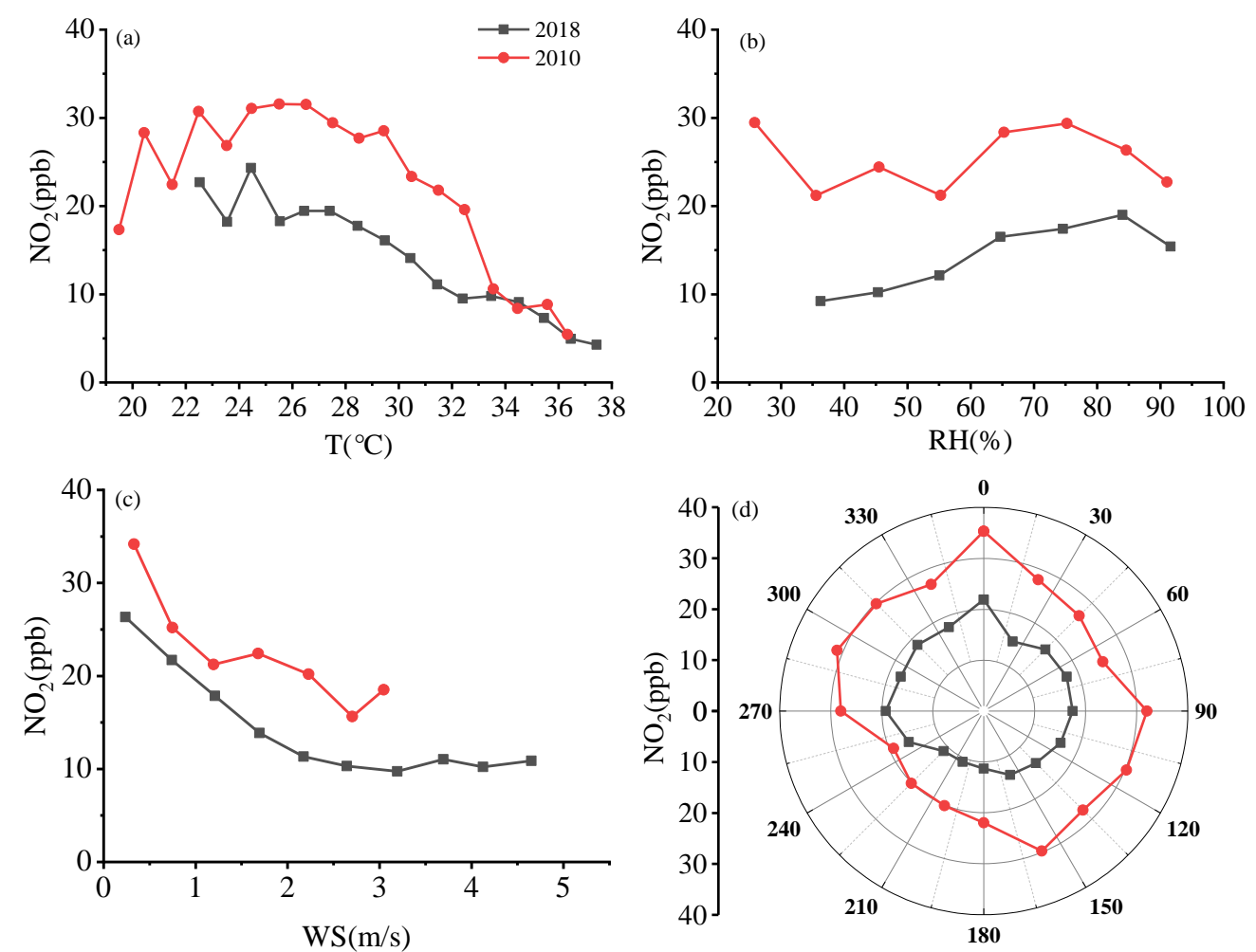

Fig. 9. Mixing ratios of $\mathrm{NO}_{2}$ in 2010 and in 2018 as functions of (a) ambient temperature, (b) relative humidity, (c) wind speed, and (d) wind direction.

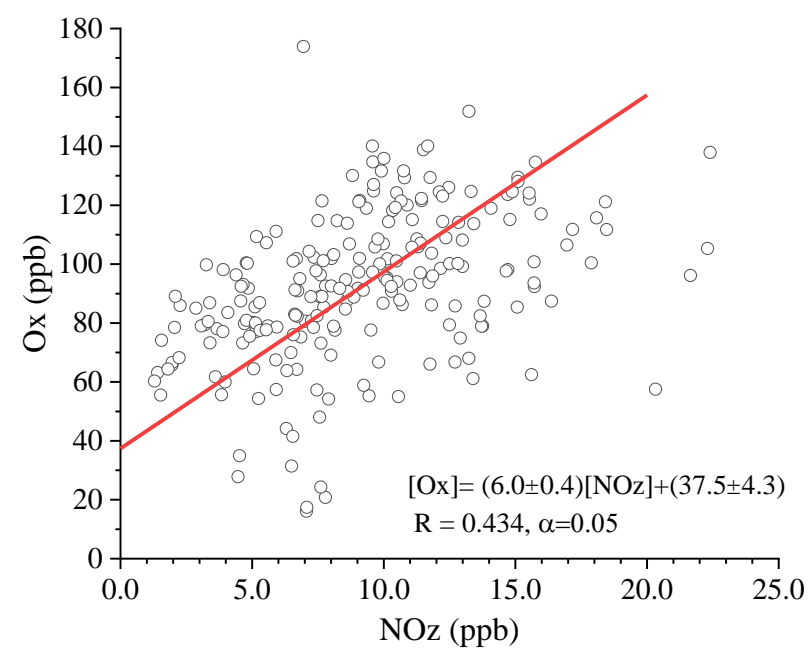

Fig. 10. Correlation between $\mathrm{O}_{x}$ and $\mathrm{NO}_{z}$ during 11:0016:00 in summer in urban Tianjin.

is more sensitive to VOCs than to $\mathrm{NO}_{x}$ in Tianjin (Han et al., 2013; Han et al., 2015). On the basis of the present results, we could only conclude that $\mathrm{O}_{3}$ increased considerably while $\mathrm{NO}_{2}$ decreased between 2010 and 2018. Lower NO chemical titration can increase the mean concentration of $\mathrm{O}_{3}$ and reduce its range, although this does not hold for daytime peak $\mathrm{O}_{3}$. Further work is needed to understand if the changes in the emission of VOCs and the ratio of VOCs to $\mathrm{NO}_{x}$ have caused the increase in surface $\mathrm{O}_{3}$ concentration.

\section{CONCLUSIONS}

An air flow drainage system utilizing a long Teflon pipe was built on a 355-m meteorological tower in urban Tianjin to obtain simultaneous measurements of gaseous pollutants at a high altitude (220 m a.g.l.) and near the surface $(3 \mathrm{~m}$ a.g.l.) during summer 2018. $\mathrm{O}_{3}$ loss in the pipeline was tested and found to be negligible, confirming that the instruments installed $3 \mathrm{~m}$ above the ground could accurately measure the concentrations of pollutants at $220 \mathrm{~m}$.

Similar variations in the concentrations at $3 \mathrm{~m}$ and $220 \mathrm{~m}$ were measured for both $\mathrm{O}_{3}$ and $\mathrm{NO}_{x}$, but noticeable differences between the two heights during the day and the night. Specifically, the diurnal $\mathrm{O}_{3}$ concentrations were higher near the surface than at the high altitude, whereas the nocturnal ones displayed the opposite trend. Also, the $\mathrm{NO}_{2}$ concentrations at $3 \mathrm{~m}$ generally exceeded those at $220 \mathrm{~m}$ by an amount that was slight during daytime but far more prominent during nighttime. The concentrations of $\mathrm{NO}$ were higher near the surface, with the largest and smallest differences between the two altitudes occurring during the day and the night, respectively. Finally, the $\mathrm{O}_{x}$ concentrations displayed significant diurnal differences but minimal nocturnal ones between the ground and the upper layer.

The concentrations of the $\mathrm{O}_{3}$ precursor $\mathrm{NO}_{x}$ were higher at $3 \mathrm{~m}$ than $220 \mathrm{~m}$, which, along with the much-increased photochemical generation of $\mathrm{O}_{3}\left(\mathrm{O}_{x}\right)$ near ground level during daytime, indicates that the surface $\mathrm{O}_{3}$ was primarily affected by local photochemical formation during the summer in urban Tianjin. From 07:00 till 14:00, the $\mathrm{O}_{3}$ 
concentration increased on average by approximately $50 \mathrm{ppb}$ near the surface and $46 \mathrm{ppb}$ in the upper layer. The measurements collected during summer 2010 reveal that the $\mathrm{NO}_{x}$ concentrations significantly decreased between this period and summer 2018, whereas the $\mathrm{O}_{3}$ concentrations increased, and the vertical structures for these pollutants also greatly changed from 2006 till 2018. Using field measurements, the summer ozone production efficiency measurement, OPE $\left(\mathrm{O}_{x} / \mathrm{NO}_{z}\right)$ was reported as $6.0 \pm 0.4$ during the summer in urban Tianjin for the first time.

\section{ACKNOWLEDGMENTS}

This study was supported by the National Natural Science Foundation Committee of China (Grant No. 91744206) and the Science and Technology Plan of Beijing (Grant No. Z181100005418016).

\section{SUPPLEMENTARY MATERIAL}

Supplementary data associated with this article can be found in the online version at https://doi.org/10.4209/aaqr.2 019.10 .0505

\section{REFERENCES}

An, J.L., Li, X, Wang, Y.S., Shi, L.Q., Hu, F. and Xu, Y.F. (2003). Measurements of atmospheric boundary layer $\mathrm{O}_{3}$, $\mathrm{NO}_{x}$ and $\mathrm{CO}$ in summer with Beijing $325 \mathrm{~m}$ meteorological tower. Environ. Sci. 24: 43-47. (in Chinese) https://doi.org/ 10.3321/j.issn:0250-3301.2003.06.007

An, J.L., Wang, Y.S., Li, X., Sun, Y., Shen, S.H. and Shi L.Q. (2007). Analysis of the Relationship between NO, $\mathrm{NO}_{2}$ and $\mathrm{O}_{3}$ Concentrations in Beijing. Environ. Sci. 28: 706711. (in Chinese)

Ding, A.J., Wang, T., Thouret, V., Cammas, J.P. and Nédélec, P. (2008). Tropospheric ozone climatology over Beijing: Analysis of aircraft data from the MOZAIC program. Atmos. Chem. Phys. 8: 1-13. https://doi.org/10.5194/acp8-1-2008

Ding, G.A., Chen, Z.Y., Gao, Z.Q., Yao, W.Q., Li, Y.X., Cheng, X.H., Meng, Z.Y., Yu, H.Q., Huang, J.H., Wang, S.F. and Miao, Q.J. (2005). Vertical structure and dynamic characteristics of $\mathrm{PM}_{10}$ and $\mathrm{PM}_{2.5}$ in Beijing urban area. Sci. China-Earth. Sci. 35: 31-44. (in Chinese)

Ge, B.Z., Xu, X.B., Lin, W.L. and Wang, Y. (2010). Observational study of ozone production efficiency at the Shangdianzi Regional Background Station. Environ. Sci. 31: 1444-1450. (in Chinese)

Haagen-Smit, A.J. (1952). Chemistry and physiology of Los Angeles Smog. Ind. Eng. Chem. Res. 44: 1342-1346. https://doi.org/10.1021/ie50510a045

Han, M., Lu, X.Q., Zhao, C.S., Ran, L. and Han, S.Q. (2015). Characterization and source apportionment of volatile organic compounds in urban and suburban Tianjin, China. Adv. Atmos. Sci. 32: 439-444. https://doi.org/10.1007/s00 376-014-4077-4

Han, S., Bian, H., Tie, X., Xie, Y., Sun, M. and Liu, A. (2009). Impact of nocturnal planetary boundary layer on urban air pollutants: Measurements from a 250-m tower over Tianjin, China. J. Hazard. Mater. 162: 264-269. https://doi.org/10.1016/j.jhazmat.2008.05.056

Han, S.Q., Zhang, M., Zhao, C.S., Lu, X.Q., Ran, L. and Han, M. (2013). Differences in ozone photochemical characteristics between the megacity Tianjin and its rural surroundings. Atmos. Environ. 79: 209-216. https://doi.o rg/10.1016/j.atmosenv.2013.06.045

Huang, H., Yao, Q., Zhang, W.Y. and Tian, X.J. (2009). Preliminary analysis of boundary layer $\mathrm{O}_{3}$ and $\mathrm{NO}_{2}$ observed in summer in Tianjin Area. Res. Environ. Sci. 22: 315-320. (in Chinese with English Abstract)

Lam, K.S., Wang, T.J., Wu, C.L. and Li, Y.S. (2005). Study on an ozone episode in hot season in Hong Kong and transboundary air pollution over Pearl River Delta region of China. Atmos. Environ. 39: 1967-1977. https://doi.org/ 10.1016/j.atmosenv.2004.11.023

Li, K., Jacob, D.J., Liao, H., Shen, L., Zhang, Q. and Bates, K.H. (2019). Anthropogenic drivers of 2013-2017 trends in summer surface ozone in China. Proc. Natl. Acad. Sci. 116: 422-427. https://doi.org/10.1073/pnas.1812168116

Lin, W.L., Xu, X.B. and Zhang, X.C. (2011). The errors in the claimed concentrations of standard gases used in the observation of reactive gases and recommended solutions. Environ. Chem. 30: 1140-1143. (in Chinese with English Abstract)

Lin, W.L., Xu, X.B., Ma, Z.Q., Zhao, H.R. and Liu, X.W. (2012). Characteristics and recent trends of surface $\mathrm{SO}_{2}$ at urban, rural, and background sites in North China: Effectiveness of control measures. J. Environ. Sci. 24: 34-49. https://doi.org/10.1016/S1001-0742(11)60727-4

Liu, S.C. (1977). Possible effects on tropospheric $\mathrm{O}_{3}$ and OH due to NO emissions. Geophys. Res. Lett. 4: 325-328. https://doi.org/10.1029/GL004i008p00325

Liu, X.H., and Hong, Z.X. (2000). Observation experiment on variation of atmospheric $\mathrm{O}_{3}, \mathrm{NO}_{x}$ and $\mathrm{CO}$ concentration in Beijing meteorological tower in autumn. Prog. Nat. Sci. 10: 338-342. (in Chinese)

Lu, K.D., Zhang, Y.H., Su, H., Shao, M., Zeng, L.M., Zhong, L.J., Xiang, Y.R., Zhang, Z.Z. and Zhou, C.G. (2010). Regional ozone pollution and key controlling factors of photochemical ozone production in Pearl River Delta during summer time. Sci. China Chem. 53: 651-663. https://doi.org/10.1007/s11426-010-0055-6

Lu, X., Hong, J., Zhang, L, Cooper, O.R., Schultz, M.G., Xu, X., Wang, T., Gao, M., Zhao, Y. and Zhang, Y. (2019). Severe surface ozone pollution in China: A global perspective. Environ. Sci. Technol. Lett. 5: 487-494. https://doi.org/10.1021/acs.estlett.8b00366

Ma, Z.Q., Wang, Y.S., Sun, Y. and Ji, D.S. (2007). Characteristics of vertical air pollutants in Beijing. Res. Environ. Sci. 20: 1-6. (in Chinese with English Abstract)

Meng, Z.Y., Ding, G.A., Yu, H.Q. and Wang, S.Y. (2002). The preliminary research on the concentration vertical distribution of $\mathrm{SO}_{2}$ and $\mathrm{NO}_{2}$ in the northern part of Beijing. J. Appl. Meteorol. Sci. 13: 109-112. (in Chinese with English Abstract)

Nunnermacker, L.J., Imre, D., Daum, P.H., Kleinman, L., Lee, Y.N., Lee, J.H., Springston, S.R., Newman, L., 
Weonstein-Lloyd, J., Luke, W.T., Banta, R., Alvarez, R., Senff, C., Sillman, S., Holdren, M., Keigley, G.W. and Zhou, X. (1998). Characterization of the Nashville urban plume on July 3 and July 18, 1995. J. Geophys. Res. 28: 129-148. https://doi.org/10.1029/98JD01961

Qiu, Y.L., Lin, W.L., Li, K., Chen, L., Yao, Q., Tang, Y.X. and Ma, Z.Q. (2019). Vertical characteristics of Peroxyacetyl Nitrate (PAN) from a 250-m tower in northern China during September 2018. Atmos. Environ. 213: 55-63. https://doi.org/10.1016/j.atmosenv.2019.05.066

Ran, L., Zhao, C.S., Geng, F., Tie, X., Tang, X., Peng, L., Zhou, G., Yu, Q., Xu, J. and Guenther, A. (2009). Ozone photochemical production in urban Shanghai, China: Analysis based on ground level observations. J. Geophys. Res. 114: D15301. https://doi.org/10.1029/2008JD010752

Ran, L., Zhao, C.S., Xu, W.Y., Han, M., Lu, X.Q., Han, S.Q., Lin, W.L., Xu, X.B., Gao, W., Yu, Q., Geng, F.H., Ma, N., Deng, Z.Z. and Chen, J. (2012). Ozone production in summer in the megacities of Tianjin and Shanghai, China: A comparative study. Atmos. Chem. Phys. 12: 7531-7542. https://doi.org/10.5194/acp-12-7531-2012

Sillman, S. (2002). The relation between ozone, $\mathrm{NO}_{x}$ and hydrocarbons in urban and polluted rural environments. Atmos. Environ. 33: 1821-1845. https://doi.org/10.1016/ S1352-2310(98)00345-8

Sun, Y., Wang, Y.S., Li, X., An, J.L., Xin, J.Y. and Hu, B. (2006). An analysis for vertical distribution of $\mathrm{O}_{3}, \mathrm{NO}_{x}$, and $\mathrm{CO}$ in the atmosphere during a serious air pollution in Beijing. Chin. J. Geophys. 49: 1475-1482. https://doi.org/ 10.1002/cjg2.974

Sun, Y., Wang, Y. and Zhang, C. (2010). Vertical observations and analysis of $\mathrm{PM}_{2.5}, \mathrm{O}_{3}$, and $\mathrm{NO}_{x}$ at Beijing and Tianjin from towers during summer and autumn 2006. $A d v$. Atmos. Sci. 27: 123-136. https://doi.org/10.1007/s00376009-8154-z

Tang, G., Wang, Y., Li, X., Ji, D. and Gao, X. (2011).
Spatial-temporal variations of surface ozone and ozone control strategy for northern China. Atmos. Chem. Phys. 11: 26057-26109. https://doi.org/10.5194/acpd-11-260572011

Tang, X.Y., Zhang, Y.H. and Shao, M. (2006). Atmospheric environmental chemistry. Higher Education Press, Beijing.

Wang, T., Ding, A., Gao, J. and Wu, W.S. (2006). Strong ozone production in urban plumes from Beijing, China. Geophys. Res. Lett. 33: L21806. https://doi.org/10.1029/2 006GL027689

$\mathrm{Xu}, \mathrm{X} . \mathrm{B}$. and Lin, W.L. (2010). Trends of tropospheric ozone over China based on the satellite data (1979-2005). Adv. Clim. Change Res. 2: 43-48. https://doi.org/10.3724/ SP.J.1248.2011.00043

Yao, Q., Ma, Z.Q., Lin, W.L., Liu, J.L., Wang, X.J., Cai, Z.Y. and Han, S.Q. (2019). Transport characteristics of PAN and $\mathrm{O}_{3}$ in the lower atmosphere of the boundary layer in Tianjin in summer. Environ. Sci. 40: 69-77. https://doi.org/ 10.13227/j.hjkx.201805070

You, Z.Q., Wei, P., Qiu, X.H., Gao, J., Zhu, Y., Wang, S.L., and Chai, F.H. (2016). Spatial and Temporal Variation of Vertical Column Density of Tropospheric $\mathrm{NO}_{2}$ over the Beijing-Tianjin-Hebei Region based on Satellite Observation during 2005-2015. Res. Environ. Sci. 29: 1400-1407. (in Chinese)

Zou, Y., Deng, X.J., Zhu, D., Gong, D.C. and Wang, H. (2015). Characteristics of 1 year of observational data of VOCs, $\mathrm{NO}_{x}$ and $\mathrm{O}_{3}$ at a suburban site in Guangzhou. Atmos. Chem. Phys. 15: 6625-6636. https://doi.org/10.51 94/acp-15-6625-2015

Received for review, October 10, 2019 Revised, March 27, 2020 Accepted, April 8, 2020 